\title{
DOI: 10.21055/0370-1069-2019-4-17-25
}

УДК 616.98:579.841.93

\author{
Ю.С. Ковтун, А.А. Курилова, Л.С. Катунина, Е.И. Василенко
}

\section{ПИТАТЕЛЬНЫЕ СРЕДЫ ДЛЯ ДИАГНОСТИКИ БРУЦЕЛЛЕЗА}

\author{
ФКУЗ «Ставропольский научно-исследовательский противочумный институт», Ставрополь, Российская Федерация
}

В обзоре приведены данные отечественной и зарубежной литературы о составе и практике применения питательных сред, используемых для диагностики бруцеллеза и производства иммунобиологических препаратов. Рассмотрены питательные среды для культивирования, выделения, накопления, идентификации и дифференциации бруцелл и их L-форм, а также синтетические и транспортные среды. Отмечены положительные и отрицательные стороны части препаратов. Представлены сведения о белковых основах, стимуляторах роста, селективных композициях и других компонентах, входящих в состав сред для диагностики бруцеллеза. Особое внимание уделено селективным средам, истории их развития и совершенствования. Обозначены требования к ингибирующим свойствам данных препаратов, показаны недостатки применения некоторых антимикробных агентов. Указаны питательные среды различного назначения, регламентированные для применения нормативно-методическими документами Российской Федерации, рекомендациями ВОЗ и Всемирной организацией по охране здоровья животных. Приведена информация о принципах оценки качества питательных сред и тест-штаммах, используемых для контроля данных препаратов по ростовым и ингибирующим показателям. Освещены тенденции разработки питательных сред для культивирования и выделения бруцелл, а также методов их применения. Выявлена необходимость проведения исследований в области разработки новых питательных сред для выделения бруцелл из материала, контаминированного посторонними микроорганизмами.

Ключевые слова: бруцеллы, питательные среды, культивирование, выделение, идентификация, тест-штаммы.

Корреспондирующий автор: Ковтун Юрий Сергеевич, e-mail: stavnipchi@mail.ru.

Для цитирования: Ковтун Ю.С., Курилова А.А., Катунина Л.С., Василенко Е.И. Питательные среды для диагностики бруцеллеза. Проблемы особо опасных инсрекций. 2019; 4:17-25. DOI: 10.21055/0370-1069-2019-4-17-25

\section{Yu.S. Kovtun, A.A. Kurilova, L.S. Katunina, E.I. Vasilenko Nutrient Media for Diagnosis of Brucellosis}

Stavropol Research Anti-Plague Institute, Stavropol, Russian Federation

Abstract. The overview contains information from Russian and foreign literature about composition and usage of nutrient media for brucellosis diagnosis and immunobiological preparations production. Nutrient media for cultivation, isolation, enrichment, identification and differentiation of Brucella and their L-form as well as transport media and synthetic media are considered. Advantages and disadvantages are described for some of the products. The overview also contains information about nutritional bases, growth factors and selective components included in these media. There is a particular focus on selective media, their history and improvement. The article gives the requirements for the inhibitory properties of these products and the disadvantages of using certain antimicrobial agents. The authors list nutrient media for various purposes, certified for use by the Russian regulatory documents, recommendations of World Health Organization and World Organization for Animal Health. Data about principles for assessing the quality of culture media and test strains used to control biological parameters of culture media are covered. The authors also present materials about the trends in nutrient media development for Brucella cultivation and isolation, methods of their application. In conclusion, they identify the need to conduct research in the sphere of the development of new nutrient media for Brucella isolation from the material contaminated by foreign microorganisms.

Key words: Brucella, nutrient media, cultivation, isolation, identification, differentiation, test strain.

Conflict of interest: The authors declare no conflict of interest.

Corresponding author: Yury S. Kovtun, e-mail: stavnipchi@mail.ru.

Citation: Kovtun Yu.S., Kurilova A.A., Katunina L.S., Vasilenko E.I. Nutrient Media for Diagnosis of Brucellosis. Problemy Osobo Opasnykh Infektsii [Problems of Particularly Dangerous Infections]. 2019; 4:17-25. (In Russian). DOI: 10.21055/0370-1069-2019-4-17-25

Received 01.10.19. Revised 31.10.19. Accepted 22.11.19.

Эпизоотолого-эпидемиологическая ситуация по бруцеллезу в России на протяжении последних лет продолжает оставаться напряженной. При наблюдаемом в последние три года снижении количества заболевших бруцеллезом людей многолетняя тенденция неблагополучия по бруцеллезу крупного рогатого скота (КРС) имеет возрастающий характер [1], вследствие чего сохраняется значимость лабораторной диагностики этого заболевания, важным компонентом которой является бактериологический ме- тод [2-4]. Эффективность данного метода во многом зависит от применяемых питательных сред. Качество питательных сред играет существенную роль также на этапах идентификации и дифференциации выделенных культур, при накоплении биомассы бруцелл в процессе производства вакцин и ряда диагностических препаратов.

Цель работы - проведение анализа данных литературы о составе, практике применения и тенденциях разработки питательных сред, используемых 
для диагностики бруцеллеза и производства иммунобиологических препаратов.

Основное требование, предъявляемое к питательным средам, независимо от их назначения, состоит в сохранении основных биологических свойств культивируемых микроорганизмов. Другим важнейшим требованием к большинству питательных сред, за исключением транспортных, является обеспечение роста микроорганизмов, т.е. удовлетворение их питательных потребностей, которые, как и условия роста, могут варьировать у представителей разных таксономических групп.

Согласно МУК 3.1.7.3402-16 «Эпидемиологический надзор и лабораторная диагностика бруцеллеза», возбудители бруцеллеза относятся к семейству Brucellaceae, роду Brucella, который включает в себя 10 самостоятельных видов, различающихся по биохимическим, метаболическим, антигенным и вирулентным характеристикам: B. melitensis, B. abortus, B. suis, B. neotomae, B. ovis, B. canis, B. ceti, B. pinnipedialis, B. microti, B. inopinata. В последние годы появились сообщения об обнаружении еще двух видов - B. papionis и B. vulpis $[5,6]$. Заболевания людей вызывают преимущественно B. melitensis, B. abortus и B. suis, биовары 1-4, режеB. canis.

Бруцеллы грамотрицательны, восстанавливают нитраты (кроме B. ovis), ферментируют глюкозу и арабинозу с образованием кислоты, цитрат не утилизируют, индол не образуют, реакции с метиловым красным и Фогеса-Проскауэра отрицательные. Уреазная активность и продукция сероводорода варьируют у разных видов и штаммов $[4,7]$. Указанные свойства микроорганизмов используются при выборе сред для выделения, идентификации и дифференциации бруцелл. Под действием антибактериальной терапии бруцеллы могут трансформироваться в L-формы [8]. Бруцеллы медленно растут на питательных средах. По данным M.J. Corbel, большинство посевов крови является положительными между 7-м и 21-м днем, только 2 \% являются положительными после 27-го дня [3]. Лабораторные культуры развиваются быстрее, но все же по скорости роста уступают большинству других микроорганизмов [9].

В диагностической, научной и производственной практике применяются питательные среды, предназначенные для культивирования, выделения, накопления, дифференциальной диагностики, транспортирования и хранения бруцелл.

Питательные среды для культивирования бруцелл. Количество питательных сред, предложенных для культивирования всех представителей рода Brucella и его отдельных видов, исчисляется десятками. Наиболее удачные из них нашли применение в практической работе микробиологов. В соответствии с МУК 4.2.3010-12 «Порядок организации и проведения лабораторной диагностики бруцеллеза для лабораторий территориального, регионального и федерального уровней» с целью проведения лабораторной диагностики бруцеллеза регламентировано применение 22 препаратов, для 6 из которых налажен промышленный выпуск. За рубежом чаще всего применяются сывороточно-декстрозный агар (SDA), коммерческие среды (соево-казеиновый агар, триптозный агар, основа кровяного агара и др.), обогащенные сывороткой, соево-казеиновый и триптозный бульоны [10-12]. Касаясь состава данных сред, следует отметить, что, помимо присутствующего во всех рецептурах хлорида натрия (обычно в концентрации 5,0 г/л) основными компонентами этих препаратов являются белковая основа (или иной источник аминокислот) и стимуляторы роста.

Белковая основа. Большинство отечественных сред лабораторного изготовления в качестве питательной основы содержат пептон ферментативный в $1 \%$ концентрации, среда-заменитель «Альбими»агара - удвоенное количество этого ингредиента. Выпускаемые коммерчески «Питательная среда для выделения и культивирования бруцелл сухая (эритрит агар)» и «Питательная среда для накопления бруцелл сухая (эритрит бульон)» в качестве единственного источника азота включают ферментативный гидролизат кильки. В состав другой, промышленно изготавливаемой в Российской Федерации, среды «Питательный агар для культивирования и выделения возбудителя бруцеллеза сухой (Бруцеллагар)», входят 3 ферментативных перевара: пептон мясной, панкреатические гидролизаты рыбной муки и казеина. В производстве иммунобиологических препаратов традиционно используется перевар Хоттингера панкреатический гидролизат мяса, в некоторых случаях в смеси с гидролизатами других белковых продуктов [13-15].

В ряде работ показана возможность успешного культивирования бруцелл на таких источниках азотистого питания, как ферментативные гидролизаты крови, желатина, сои, соевого концентрата, глютена кукурузного, рыбной кормовой муки, плацентарноэмбрионально-маточный гидролизат, дрожжевой автолизат, патока и др. [16-21]. Зарубежные среды аналогичного назначения в качестве белковой основы включают ферментативные гидролизаты казеина, пептические перевары животной ткани, папаиновые перевары соевой муки, бактериологические пептоны и триптозу. Качеству пептонов при этом уделяется повышенное внимание - в некоторых руководствах указаны проверенные, положительно зарекомендовавшие себя компании-производители [3]. Из вышеприведенных данных следует, что спектр белоксодержащих продуктов, служащих для получения источников азотистого питания при культивировании бруцелл, достаточно широк и включает сырье животного и растительного происхождения.

Стимуляторы роста. Большинство штаммов бруцелл требуют для своего роста различные аминокислоты, витамины: тиамин, биотин, никотинамид, пантотеновую кислоту и другие соединения, 
особенно при первичной изоляции, вследствие чего большинство питательных сред для их культивирования, помимо белковых гидролизатов, содержат экстракты животного, растительного или микробного происхождения, сыворотку, кровь, витамины, углеводы, а также многоатомные спирты $[8,11,12]$. Среди наиболее распространенных - мясные, печеночные и картофельные настои и дрожжевые экстракты. Почти во все рецептуры включена глюкоза в концентрации 1,0-10,0 г/л. В состав эритрит агара, эритрит бульона, бруцеллагара, одного из вариантов триптозного агара/бульона, выпускаемого фирмой HiMedia Laboratories Pvt. Limited (Индия), входит тиамин, а в состав первых трех из перечисленных сред - четырехатомный спирт эритрит, являющийся предпочтительным источником энергии для многих штаммов бруцелл $[12,22,23]$. Следует подчеркнуть, что данные о влиянии эритрита на рост бруцелл неоднозначны. Данное соединение стимулировало рост $B$. melitensis, но замедляло рост некоторых других штаммов, в частности, B. abortus S 19 [23, 24]. Трехатомный спирт глицерин также нашел применение в качестве стимулятора роста бруцелл, однако в значительно более высоких концентрациях (10-30 г/л), чем эритрит (0,01-0,0122 г/л). Высокие концентрации глицерина $(1,0-3,0$ \%) и глюкозы $(0,5-$ $1,5 \%$ ), наряду с повышенным содержанием источников азотистого питания, позволяют интенсифицировать получение биомассы бруцелл при производстве иммунобиологических препаратов [14, 25]. В составе бруцеллагара присутствует и стимулятор роста гемофильных микроорганизмов, хотя следует отметить, что бруцеллы для своего роста не нуждаются в гемине и никотинамидадениндинуклеотиде [10]. Содержащиеся в некоторых средах натрий сернистокислый или пиросернистокислый, а также L-цистин могут как регулировать окислительновосстановительный потенциал, так и служить источниками серы. В рецептуре ряда сред, таких как соево-казеиновый агар/бульон, обогащенный агар/ бульон, эритрит агар и эритрит бульон отсутствуют настои или экстракты, однако входящие в них гидролизаты, прежде всего гидролизаты соевой муки и кильки, богаты витаминами, микроэлементами и другими факторами роста [26].

Синтетические среды. С первой половины $\mathrm{XX}$ в. и до настоящего времени для изучения питательных потребностей, биохимических особенностей бруцелл и их культивирования предложено большое количество синтетических питательных сред. В их рецептуры входила минеральная основа, включающая чаще всего фосфорнокислые соли калия и натрия, сульфаты магния и аммония, хлориды натрия и аммония, органические вещества - глюкозу, глицерин, пируват и цитрат натрия, а также факторы роста - аминокислоты и витамины. Число аминокислот в них варьировало от 1 до 6, наиболее часто встречались 1-глутаминовая кислота, 1-аргинин, 1-гистидин, 1-лизин, d1-метионин, 1-цистеин, 1-цис- тин и 1-аланин. Комбинации витаминов, как правило, представлены тиамином, никотиновой и пантотеновой кислотами, биотином, рибофлавином, пиридоксином и состояли из 2-6 соединений [27-30]. Ростовые свойства этих сред разнились в достаточно большой степени. Препараты различались по количеству вырастающих на них видов и штаммов бруцелл [28, 29, 31]. Посев на большинство синтетических сред осуществлялся с использованием массивных посевных доз $\left(2 \cdot 10^{3}-1 \cdot 10^{7}\right.$ микробных клеток), однако некоторые из препаратов позволяли выявить рост единичных колоний $[28,32]$. Эффективность синтетических сред, как правило, была невысока $-10^{7}-10^{8}$ м.к. с 1 мл среды, но в ряде случаев среды позволяли получить с 1 мл до 2,0-19,0 млрд м.к. [27, 29].

Наряду с препаратами для изучения питательных потребностей и культивирования, предложена и синтетическая среда для определения сахаролитической активности бруцелл, которая, по данным авторов, позволяет в короткий срок (48-72 ч) выявить сахаролитические свойства бруцелл, что невозможно при использовании сред Гисса из-за выраженной дезаминирующей активности этих микробов [33].

Питательные среды для выделения бруцелл. Выделение возбудителей бруцеллеза из крови, костного мозга, спинномозговой жидкости и других объектов, не содержащих в норме микроорганизмы, проводят с помощью сред для культивирования бруцелл, обладающих хорошими ростовыми свойствами. Добавление инактивированной нагреванием при $56^{\circ} \mathrm{C}$ в течение 30 мин сыворотки крови крупного рогатого скота или лошади повышает чувствительность сред к росту бруцелл и необходимо для выделения B. abortus 2 биовара и B. ovis. Для изоляции этих микроорганизмов из контаминированного материала требуется наличие в питательной среде ингибиторов посторонней микрофлоры, в противном случае последняя подавит рост бруцелл, медленно растущих и взыскательных к источникам питания $[23,34]$. Ингибиция должна быть комплексной и направленной на угнетение роста грамположительных, грамотрицательных бактерий и микофлоры [35].

Одним из первых селективных агентов, использованных для выделения B. abortus, стал генцианвиолет, который вводился в шоколадный агар или агар, изготовленный на основе печеночного настоя [36, 37]. В дальнейшем С.A. Kuzdas и E. Morse разработали среду, обозначенную ими как $\mathrm{W}$, усилив ее ингибирующие свойства за счет добавления к 1,4 мг кристаллического фиолетового 6 тыс. единиц полимиксина В сульфата, 100 мг актидиона, 25 тыс. единиц бацитрацина, 15 тыс. единиц циркулина [38]. Предложены варианты этой среды, в которых генцианвиолет заменен на другие красители и исключен циркулин. Один из таких вариантов, содержащий 1,25 мг/л этилвиолета, выпускался фирмами Biolife Italiana S.r.1. и Merck KGaA до недавнего времени. В ходе использования данных сред в практической работе выявилось, что среды, включающие в качестве 
селективных агентов красители, не поддерживают poст $B$. abortus биовара 2 и некоторых других видов. L.M. Jones и W.J. Brinley Morgan предложили сывороточный глюкозный агар, на котором наблюдался хороший рост всех штаммов бруцелл, в том числе и рост биовара 2 B. abortus. Агар содержал в качестве селективных агентов $25000 \mathrm{ME} / л$ бацитрацина, $6000 \mathrm{ME} /$ п полимиксина и 4 мг/л амфотерицина [39]. Обладая хорошими вегетирующими свойствами в отношении бруцелл, данная среда была недостаточно селективна, поэтому эффективность выделения бруцелл при ее использовании уступала эффективности биологического метода [11].

Среда, разработанная Ryan, содержала пенициллин, ристоцетин, полимиксин В, налидиксовую кислоту, цетримид, нистатин, циклогексимид и 5 \% крови. Эта среда ингибировала рост B. abortus biovar 2 и была эффективна только для контроля умеренного загрязнения [40].

Высокоселективную питательную среду, обеспечивающую выделение большого количества штаммов бруцелл, в том числе и B. abortus биоваpa 2, разработал I.D. Farrell [41]. Среда готовится на основе сывороточно-глюкозного агара и содержит $25000 \mathrm{ME} / л$ бацитрацина, 20 мг/л ванкомицина, $5000 \mathrm{ME} /$ л полимиксина, 5 мг/л налидиксовой кислоты, 100 мг/л циклогексимида и $100000 \mathrm{ME} / л$ нистатина. В последствии, ввиду высокой токсичности для человека циклогексимида, последний заменен на натамицин, обладающий сходной антимикотической активностью [42]. Среда Farrell, вероятно, является наиболее широко используемой селективной средой для бактериологической диагностики бруцеллеза, ее применение рекомендовано ВО3 и Всемирной организацией по охране здоровья животных [3, 4, 43]. Композиции ингибиторов посторонней микрофлоры, включающие как циклогексимид, так и натамицин, выпускаются рядом зарубежных фирм $[11,12]$. Вместе с тем, содержащиеся в этой среде бацитрацин и налидиксовая кислота в регламентированных концентрациях сильно ингибируют $B$. ovis и B. suis, некоторые штаммы B. melitensis и B. abortus [43-45].

C.M. Marín et al. показали, что модифицированная среда Thayer-Martin более чувствительна к росту бруцелл, чем среда Farrell, а максимальное выделение бруцелл из контаминированного материала наблюдается при одновременном применении этих двух сред [44]. Модифицированная среда ThayerMartin включает основу питательной среды для культивирования гонококков, гемоглобин - 10 г/л, метансульфонат колистина - 7,5 мг/л, ванкомицин - 3 мг/л, нитрофурантоин - 10 мг/л и нистатин - $12500 \mathrm{ME} /$ л. Совместное использование питательных сред рекомендовано для рутинной бактериологической диагностики заболевания [46]. Отрицательными свойствами модифицированной среды Thayer-Martin явились недостаточная селективность и непрозрачность, затрудняющая визуальное наблюдение за морфологией вырастающих колоний [43].
Недостатки модифицированной среды ThayerMartin устранены De Miguel et al. в ходе разработки среды CITA [43]. С целью повышения прозрачности разработчики исключили из рецептуры гемоглобин и заменили основу питательной среды для культивирования гонококков на основу кровяного агара с добавлением 5 \% телячьей сыворотки. Ингибирующие свойства среды усилены за счет увеличения содержания ванкомицина до 20 мг/л и включения в состав препарата 4 мг/л амфотерицина В. Авторы считают, что предложенная ими среда может применяться для успешного выделения всех видов бруцелл из полевых ветеринарных образцов, однако отмечают преимущество одновременного использования CITA со средой Farrell или модифицированной средой ThayerMartin для выделения B. melitensis, B. suis или B. ovis. M.S. Karagül и S. İkiz, сравнивая выделение бруцелл с помощью селективных сред Farrell, CITA, Jones and Morgan, модифицированной среды Thayer-Martin и ингибирующие свойства данных сред в отношении посторонней микрофлоры, также пришли к выводу о предпочтительном использовании двух сред, одной из которых должна быть среда Farrell [47].

В настоящее время совместное применение сред Farrell и CITA рекомендовано Всемирной организацией по охране здоровья животных [4].

Для выделения бруцелл из контаминированного материала, содержащего малое количество микроорганизмов, ВО3 и Всемирная организация по охране здоровья животных регламентируют использование бифазной среды, обе фазы которой представляют собой модифицированную среду Brodie and Sinton, содержащую следующую селективную композицию (г/л): полимиксин В сульфат - $6000 \mathrm{ME}$, бацитрацин $25000 \mathrm{ME}$, натамицин - 50 мг, налидиксовая кислота - 5 мг, амфотерицин В - 1 мг, ванкомицин - 20 мг и Д-циклосерин - 100 мг. Эта среда в большей степени ингибирует рост бактерий Pseudomonas, Proteus, Alkaligenes faecalis, Bacillus cereus и Citrobacter freundii, чем среда Farrell [3, 4, 48].

В нашей стране в качестве селективных агентов при выделении бруцелл МУК 3.1.7.3402-16 регламентировано применение генцианвиолета в концентрации 5 мг/л и смеси антибиотиков полимиксина 3 мг/м и амфоглюкамина -3 мг/л. Из этих двух антибиотиков состоят селективные добавки СД-1 и СД-2, прилагаемые к бруцеллагару производства ФБУН ГНЦ ПМБ. В ветеринарной практике, в соответствии с «Наставлением по диагностике бруцеллеза животных» № 13-5-02/0850 от 29.09.2003 г., нашли применение генцианвиолет и малахитовый зеленый в концентрации 5 мг/л, кристаллвиолет - 10 мг/л, уксуснокислый натрий - 125 мг/л. С целью расширения спектра ингибируемой микрофлоры отечественными исследователями разработан ряд селективных композиций. В.Г. Дальвадянц и В.И. Щедрин, изучая различные концентрации невиграмона, цефокситина, полимиксина, олеандомицина, хлорамфеникола, карбенициллина и генцианвиолета, при помощи со- 
четания оптимальных концентраций полимиксина и генцианвиолета выделили культуру бруцелл из суспензии почвенного экстракта, контаминированного штаммами кишечной палочки, бруцелл, протея и стафилококка. Комбинация кристаллического фиолетового и налидиксовой кислоты позволяла при успешном выделении бруцелл ингибировать рост большого числа посторонних микроорганизмов, в частности, видов Staphylococcus aureus, Escherichia coli и Proteus vulgaris [49]. Для более сильного подавления сопутствующей микрофлоры МУК 4.2.3010-12 предусматривают использование рекомендованной Комитетом экспертов ФАО/ВОЗ по бруцеллезу прописи модифицированной среды Brodie and Sinton. Вместе с тем следует отметить, что коммерческая добавка по данной рецептуре в нашей стране не выпускается, мы не обнаружили ее и в зарубежных источниках. Составляющие добавку антимикробные соединения малодоступны для практических учреждений, активность данных соединений может сильно варьировать, и для корректного применения необходима отработка рабочей дозы [50].

C целью выделения L-форм бруцелл предложены питательные среды, характеризующиеся повышенным содержанием стимуляторов роста, обязательным наличием нормальной лошадиной сыворотки, L-трансформирующих агентов или селективных агентов в концентрациях, кратно превышающих обычно применяемые при изоляции бруцелл [51]. Так, содержание кристаллического фиолетового, согласно рецептуре среды данного назначения, приведенной в МУК 3.1.7.3402-16, доходит до 30 мг/л, налидиксовой кислоты (в соответствии с патентом РФ 2415918) - до 50 мг/л [52]. Добавление в питательные среды бициллина-3 в концентрациях 3000 ЕД/мл и выше, по данным Л.М. Михайлова и соавт., ингибирует рост бруцелл в $\mathrm{S}$-форме и не влияет на L-форму [53].

Для обеспечения надлежащего качества бактериологических исследований каждая серия среды для выделения и культивирования бруцелл должна контролироваться по биологическим показателям. ВО3 рекомендует проверку основных сред по их способности поддерживать рост наиболее требовательного к наличию сыворотки штамма B. abortus биотипа 2 при малой посевной дозе (5-10 м.к.) [10]. В соответствии с МУ 3.3.2.2124-06 «Контроль диагностических питательных сред по биологическим показателям для возбудителей чумы, холеры, сибирской язвы, туляремии, бруцеллеза, легионеллеза», препараты данного назначения должны оцениваться по показателям чувствительности, прорастания, скорости роста, эффективности и стабильности биологических свойств культур. Испытание осуществляется с помощью тест-штаммов B. abortus 19 BA, B. melitensis 16 М и B. suis 1330. Для оценки ингибирующих свойств селективной среды в отношении сопутствующей микрофлоры фирма «Oxoid Limited» использует тест-штамм S. aureus ATCC 25923, фирма
«HiMedia Laboratories Pvt. Limited» - тот же штамм золотистого стафилококка и дополнительно тестштамм E. coli ATCC 25922 [11, 12]. Аналогичный показатель бруцеллагара контролируется с помощью тест-штаммов E. coli ATCC 25922 и Candida albicans 60193, рост которых при посеве 0,1 мл микробной взвеси из разведения $10^{-4}$ должен полностью подавляться не позднее 48-72 ч инкубации при температуре $(37 \pm 1){ }^{\circ} \mathrm{C}$.

Среды для идентификации и дифференциации бруцелл. С целью установления принадлежности выделенной культуры к роду Brucella могут быть выполнены соответствующие тесты с использованием следующих питательных сред: глюкозо-пептонной среды - для теста с метиловым красным и ФогесаПроскауэра; цитратной среды Козера - с целью определения способности утилизировать цитрат натрия; питательного бульона - для определения индолообразования; глюкозо-пептонной воды с индикатором и поплавком - для обнаружения газообразования; питательного желатина - для выявления протеолитической активности, нитратного бульона - для определения нитратредуктазы. За исключением определения нитратредуктазы (кроме B. ovis, не редуцирующей нитрат), положительные результаты остальных тестов, как правило, исключают принадлежность испытываемой культуры к роду Brucella [8, 54].

После установления принадлежности к роду для корректного определения видовой принадлежности бруцелл выделенную культуру изучают на наличие диссоциации. Культуру, подвергаемую данному исследованию, рекомендуется выращивать на плотной питательной среде, содержащей $2 \%$ глицерина и $1 \%$ глюкозы [10]. Проведение дифференциации бруцелл по способности образования сероводорода осуществляют с помощью печеночного агара или сывороточно-декстрозного агара [9]. Редуцирующую активность в отношении красок определяют на мясопептонном агаре, агаре Альбими, других агаровых средах для культивирования бруцелл, за исключением сильно пигментированных и непрозрачных [10].

Tранспортные среды. Используются для доставки биоматериала в специализированные организации. В частности, с указанной целью может использоваться среда Amies [10]. В Российской Федерации Ставропольский противочумный институт выпускает питательную среду жидкую для транспортировки биоматериала и накопления бруцелл (регистрационное удостоверение № РЗН 2013/1153 от 09.09.2013 г.), включающую гидролизат Хоттингера, натрий хлористый, глицерин, глюкозу, натрий лимоннокислый и липоевую кислоту. Среда предназначена для сбора, транспортировки неконтаминированного посторонней микрофлорой биоматериала (кровь, спинномозговая жидкость, костный мозг, желчь), полученного от пациентов, подозрительных на заболевание бруцеллезом, и накопления бруцелл видов B. melitensis, B. abortus и B. suis. Препарат разлит в пенициллиновые флаконы, стерилен, готов к упо- 
треблению. До транспортировки флаконы с посевами биоматериала допускается хранить в термостате, при комнатной температуре или в холодильнике не более 2 недель.

Из анализа приведенной информации следует, что для культивирования бруцелл предложено большое количество питательных сред, 22 из которых регламентированы нормативными документами, а 6 выпускаются в России промышленным способом. В отечественной лабораторной практике используется также ряд питательных сред зарубежного производства. В качестве белковой основы как российских, так и импортных препаратов применяются: пептон ферментативный, перевары мяса, ферментативный гидролизат кильки, панкреатические гидролизаты рыбной либо соевой муки, казеина и др. Разнообразен спектр стимуляторов роста, используемых в составе питательных сред для культивирования бруцелл, что обусловлено их высокой потребностью в аминокислотах, витаминах, углеводах, микроэлементах и других факторах роста. Синтетические среды, представленные достаточным перечнем и предназначенные, в основном, для изучения питательных потребностей и биохимических свойств возбудителя бруцеллеза, для культивирования сейчас применяются нечасто. Среды для идентификации и дифференциации бруцелл позволяют с помощью специальных тестов установить род и вид выделенных культур.

Ассортимент транспортных бруцеллезных сред не столь обширен, при этом существующие препараты, несмотря на устойчивый спрос, не всегда удовлетворяют требованиям бактериологической практики. Так, например, нет среды для транспортировки биоматериала, подлежащего исследованию на бруцеллез и контаминированного посторонними микроорганизмами. Разработка такой питательной среды необходима. Целесообразными представляются и работы, направленные на расширение спектра транспортных питательных сред для бруцелл, что будет способствовать созданию базы сред выбора и, следовательно, обеспечению непрерывности диагностических исследований в случае непредвиденных затруднений с производством либо наличием того или иного компонента производимых сред.

Питательные среды для выделения возбудителей бруцеллеза из стерильных в норме биологических объектов должны обладать повышенной чувствительностью, для чего в их составе требуется наличие сывороток - лошадиной или КРС. Для выделения L-форм, помимо обогащения сыворотками и стимуляторами роста, необходимо введение L-трансформирующих или селективных агентов в высоких концентрациях. Изоляция бруцелл из контаминированного посторонней микрофлорой материала требует наличия в среде ингибиторов, подбор которых должен учитывать чувствительность к ним как контаминантов, так и самих бруцелл. В настоящее время для повышения числа изолированных культур рекомендуется применять не менее двух сред с разными комбинациями ингибирующих агентов. В последние годы в России промышленным способом выпускается только одна среда для выделения бруцелл, обладающая недостаточно широким спектром селективного действия. Среди всех разработанных сред данного назначения пока нет единого удобного в применении варианта, который, имея в составе стандартные и доступные компоненты и отвечая основным требованиям к качеству микробиологических сред, полностью удовлетворял бы ростовым потребностям всех культивируемых штаммов бруцелл, не ингибируя их роста, при этом обладал полноценной селективностью и не содержал токсичные для человека ингредиенты.

Таким образом, в условиях сохраняющейся неблагоприятной эпизоотолого-эпидемиологической ситуации в России по бруцеллезу, для его своевременной и качественной лабораторной диагностики необходимо постоянное наличие питательных сред различного назначения, отвечающих всем требованиям, предъявляемым к микробиологическим средам, для чего качеству их должно уделяться повышенное внимание. Наиболее приоритетными к настоящему моменту представляются исследования в области разработки новых сред для изоляции бруцелл из контаминированного посторонними микроорганизмами материала.

Конфликт интересов. Авторы подтверждают отсутствие конфликта финансовых/нефинансовых интересов, связанных с написанием статьи.

\section{Список литературы}

1. Пономаренко Д.Г., Ежлова Е.Б., Русанова Д.В., Хачатурова А.А., Пакскина Н.Д., Бердникова Т.В., Манин Е.А., Семенко О.В., Логвиненко О.В., Ракитина Е.Л., Костюченко М.В., Малецкая О.В., Куличенко А.Н. Анализ эпизоотологоэпидемиологической обстановки по бруцеллезу в Российской Федерации в 2018 г. и прогноз на 2019 Г. Проблемы особо опасныхх инфекиий. 2019; 2:14-21. DOI: 10.21055/0370-1069-2019-214-21.

2. Онищенко Г.Г., Кутырев В.В., редакторы. Лабораторная диагностика опасных инфекционных болезней. Практическое руководство. М.: ЗАО «Шико»; 2013. 560 с.

3. Corbel M.J. Food and Agriculture Organization of the United Nations, World Health Organization, World Organization for Animal Health. Brucellosis in humans and animals. Geneva; 2006. 89 p.

4. World Organization for Animal Health. Terrestrial Manual. [Электронный pecypc]. URL: https://www.oie.int/fileadmin/Home/ eng/Health standards/tahm/3.01.04_BRUCELLOSIS.pdf (дата обращения 2र2.08.2019).

5. Whatmore A.M., Davison N., Cloeckaert A., Al Dahouk S. Zygmunt M.S., Brew S.D., Perrett L.L., Koylass M.S., Vergnaud G., Quance C., Scholz H.C., Dick E.J. Jr., Hubbard G., SchlabritzLoutsevitch N.E. Brucella papionis sp. nov., isolated from baboons (Papio spp.). Int. J. Syst. Evol. Microbiol. 2014; 64(Pt 12):4120-8. DOI: 10.1099 /ijs.0.065482-0.

6. Scholz H.C., Revilla-Fernández S., Al Dahouk S., Hammerl J.A., Zygmunt M.S., Cloeckaert A., Koylass M.S., Whatmore A.M., Blom J., Vergnaud G., Witte A., Aistleitner K., Hofer E. Brucella vulpis sp. nov., isolated from mandibular lymph nodes of red foxes (Vulpes vulpes). Int. J. Syst. Evol. Microbiol. 2016; 66(5):2090-8. DOI: 10.1099/1jsem.0.000998.

7. Казанев А.П., Буланьков Ю.И. Бруцеллез. В кн.: Лобзин Ю.В., Жданов К.В, редакторы. Руководство по инфекционным болезням. В 2 кн. Кн. 1. СПб: ООО «Издательство Фолиант»; 2011. C. 389-400.

8. Министерство здравоохранения Российской Федерации. Бруцеллез у взрослых. Клинические рекомендации. 2014. 71 с.

9. Таран И.Ф., Лямкин Г.И. Бруцеллез (микробиология, иммунология, эпидемиология, профилактика). Ставрополь; 1996. $172 \mathrm{c}$

10. Joint FAO/WHO expert committee on brucellosis. World 
Health Organ. Tech. Rep. Ser. 1986; 740:1-132. PMID: 3097967. 11. The OXOID MANUAL. 9th Edition. 2006. 624 p.

12. Диагностика особо опасных инфекций (ООИ). HiMedia Laboratories Pvt. Limited (Индия). [Электронный pecypc]. URL: http://www.himedialabs.ru/ooi/ (дата обращения 22.08.2019).

13. Соболев В.В., Мельник Н.В., Скляров О.Д., Тройнин А.С., Зенов Н.И., Климанов А.И., Шумилов К.В., Литенкова И.Ю., Рахманин П.П., Крюков С.В., Тренев В.Н., Соловьев Б.В., Балашов В.Г. Способ получения бруцеллезного антигена из штамма Brucella abortus 19 для изготовления единого бруцеллезного антигена для РА, РСК и РДСК, бруцеллезного антигена для розбенгал пробы (РБП) и бруцеллезного антигена для кольцевой реакции (КР) с молоком, способ изготовления бруцеллезной диагностической сыворотки и диагностические наборы. Патент РФ № 2361610, опубл. 20.07.2009 г. Бюл. № 20.

14. Пяткова Н.В., Суслопаров А.А., Федотов А.К., Юдников В.А., Полищук В.И., Охапкина В.Ю., Дармов И.В. Способ получения биомассы бруцелл вакцинных штаммов при глубинном выращивании с использованием жидкой питательной среды минимизированного состава. Патент РФ 2687373, опубл. 13.05.2019 г. Бюл. № 14.

15. Кабахова П.М., Хаиров С.Г., Юсупов О.Ю., Яникова Э.А. Сравнительное изучение разных питательных сред для промышленного культивирования бруцелла абортус 19. Ветеринарная медииина. 2014; 2:6-8.

16. Девришов Д.А., Шведов В.В., Шведов Д.В., Бедоева 3.М. Сравнительная оценка ростовых свойств производственных культур бруцелл на различных питательных средах Ветеринарная медиина. 2014; 1:19-34.

17. Ковтун Ю.С., Курилова А.А., Катунина Л.С, Василенко Е.И. Сравнительная оценка белковых гидролизатов при разработке на их основе питательной среды для культивирования бруцелл. Проблемы особо опасныхх инфекиий. 2016; 4:93-7. DOI: 10.21055/0370-1069-2016-4-93-97.

18. Мамлеева Н.К., Торбина М.П., Белозерова Г.А. Питательная среда для диагностики бруцеллеза. Авторское свидетельство СССР № 1806186, опубл. 30.03.1993 г. Бюл. № 12

19. Зайцева А.И. Изучение эффективности лечебной бруцеллезной вакцины, приготовленной на среде с дрожжевым автолизатом. Журнал микробиологии, эпидемиологии и иммунобиологии. $1961 ; 1: 107-10$.

20. Иванов М.М., Михайлов Н.А. Питательная среда для выращивания микроорганизмов. Авторское свидетельство СССР № 382682, опубл. 23.05.1973 г. Бюл. № 23.

21. Головнева С.И., Лямкин Г.И., Катунина Л.С., Ляпустина Л.В., Старцева О.Л., Малецкая О.В., Ефременко В.И. Питательная среда для культивирования бруцелл. Патент РФ № 2299238, опубл. 20.05.2007 г. Бюл. № 14.

22. Tripathi K.K., Bhatnagar L., Seiffge D., Jankowski R.P., Aikins H.E. Gupta K.G. On the growth of Brucella species in presence of erythritol in defined and undefined media and amniotic fluid of human, cow and sheep. Zentralbl. Bakteriol. Orig. A. 1977; 237(2-3):324-9.

23. Karagül M.S. Evaluation of adding erythritol to Farrell medium for primary isolation of the Brucella melitensis strains. Kocatepe Vet. J. 2019; 12(1):75-81. DOI: $10.30607 / \mathrm{kvj} .494891$.

24. Miranda K.L., Dorneles E.M.S., Poester F.P., Martins Filho P.S., Pauletti R.B., Lage A.P. Different resistance patterns of reference and field strains of Brucella abortus. Braz. J. Microbiol. 2015; 46(1):265-9. DOI: 10.1590/S1517-838246120130625.

25. Девришов Д.А., Кабардиев С.Ш., Юсупов О.Ю. Способ изготовления вакцины против бруцеллеза мелкого рогатого скота. Патент РФ № 2642316, опубл. 24.01.2018 г.

26. Обзор основных компонентов питательных сред. [Электронный pecypc]. Справочник по микробиологии Merck питательные среды, добавки, экспресс-тесты, пробоотборники воздуха. 679 c. URL: http://www.dia-m.ru/upload/iblock/34b/ Справочник\% 20по\% 20микробиологии\%20Merck\%20-\%20питательные\% $\%$ срреды, \%20добавки, \%20экспресс-тесты,\%20пробоотборники $\% 20$ воздуха,\%20русск.,\%20679\%20стр..pdf (дата обращения 22.08.19 г.)

27. Gerhardt P., Wilson J.B. The nutrition of brucellae: growth in simple chemically defined media. J. Bacteriol. 1948; 56(1):17-24. PMID: 16561542. PMCID: PMC518538.

28. Rode L.J., Oglesby G., Schuhardt V.T. The cultivation of brucellae on chemically defined media. J. Bacteriol. 1950; 60(5):661-8.

29. Цыганкова Р.Е., Майский В.Г., Ляпустина Л.В., Лямкин Г.И. Синтетическая питательная среда для выращивания бруцелл. Патент РФ 2148638, опубл. 10.05.2000 г.

30. Pérez-Etayo L., de Miguel M.J., Conde-Álvarez R., Muñoz P.M., Khames M., Iriarte M., Moriyón I., Zúñiga-Ripa A. The $\mathrm{CO}_{2}-$ dependence of Brucella ovis and Brucella abortus biovars is caused by defective carbonic anhydrases. Vet. Res. 2018, 49(1):85. DOI: 10.1186/s13567-018-0583-1

31. Меринов С.П., Широков В.А., Голубинский Е.П., Пинигин А.Ф., Петухова О.С. Синтетическая питательная сре- да для выращивания бруцелл. Авторское свидетельство СССР № 933702, опубл. 07.06.1982 г. Бюл. № 21 .

32. Донской Д.Н., Пинигин А.Ф., Голубинский Е.П., Меринов С.П. Минимальная синтетическая питательная среда для Brucella. Журнал микробиологии, эпидемиологии и иммунобиологии. 1983; 11:112.

33. Алимов А.М., Зайнеев Н.Ш., Салмаков К.М., Хазипов Н.3. Синтетическая среда для определения сахаролитической активности бруцелл. Авторское свидетельство СССР 1210453 , опубл. 23.03.1988 г. Бюл. № 11.

34. Marín C.M., Alabart J.L., Blasco J.M. Effect of antibiotics contained in two Brucella selective media on growth of Brucella abortus, B. melitensis, and B. ovis. J. Clin. Microbiol. 1996; 34(2):426-8.

35. Hornsby R.L. Selective media for isolation of Brucella abortus strain RB51. 1998. [Электронный pecypc]. URL: https:// lib.dr.iastate.edu/cgi/viewcontent.cgi? article $=18852 \&$ context $=$ rtd (дата обращения 22.08.2019).

36. Huddleston I. Forrest, Hasley D.E., Torrey J.P. Further studies on the isolation and cultivation of Bacterium abortus (Bang). J. Infect. Dis. 1927; 40(20):352-68. DOI: 10.1093/infdis/40.2.352.

37. Henry B.S., Traum J., Haring C.M. Methods for the isolation of Brucella abortus. Hilgardia. 1932; 6(12):355-79. DOI: 10.3733/hilg.v06n12p355.

38. Kuzdas C.D., Morse E.V. A selective medium for the isolation of brucellae from contaminated materiales. J. Bacteriol. 1953; 66(4):502-4. PMID: 13096514. PMCID: PMC317420.

39. Jones L.M., Morgan W.J.B. A preliminary report on a selective medium for the culture of Brucella, including fastidious types Bull. World Health Organ. 1958; 19(1):200-3.

40. The Modification of Technical Annexes of Council Directive 64/432/EEC to take account of Scientific Developments regarding Tuberculosis, Brucellosis and Enzootic Bovine Leucosis. [Электронный pecypc]. URL: http://ec.europa.eu/food/sites/food/ files/safety/docs/sci-com_scah_out33_en.pdf (дата обращения 22.08.19 г.)

41. Farell I.D. The development of a new selective medium for the isolation of Brucella abortus from contaminated sources. Res. Vet. Sci. 1974; 16(3):280-6. DOI: 10.1016/S0034-5288(18)33726-3. 42. Stack J.A., Harrison M., Perrett L.L. Evaluation of a selective medium for Brucella isolation using natamycin. J. Appl Microbiol. 2002; 92 (4):724-8. DOI: 10.1046/j.1365-2672.2002.01595.x.

43. De Miguel M.J., Marin C.M., Munoz P.M., Dieste L., Grillo M.J., Blasco J.M. Development of a selective culture medium for primary isolation of the main Brucella species. J. Clin. Microbiol. 2011; 49(4):1458-63. DOI: 10.1128/JCM.02301-10.

44. Marin C.M., Jiménez de Bagüés M.P., Barberán M., Blasco J.M. Comparison of two selective media for the isolation of Brucella melitensis from naturally infected sheep and goats. Vet Rec. 1996; 138(17):409-11. DOI: 10.1136/vr.138.17.409.

45. Vicente A.F., Antunes J.M.A.P., Lara G.H.B., Mioni M.S.R., Allendorf S.D., Peres M.G., Appolinário C.M., Listoni F.J.P., Ribeiro M.G., Megid J. Evaluation of three formulations of culture media for isolation of Brucella spp. regarding their ability to inhibit the growth of contaminating organisms. Biomed. Res. Int. 2014; 2014:702072. DOI: $10.1155 / 2014 / 702072$.

46. World Organization for Animal Health. Manual of diagnostic tests and vaccines for terrestrial animals. 6th ed. OIE; 2008 . P. 628.

47. Karagül M.S., İkiz S. Comparison of the isolation and inhibition abilities of selective media used for Brucella spp. Isolation. Turk. J. Vet Anim. Sci. 2017; 41:781-6. DOI: 10.3906/vet-1701-50.

48. Brodie J., Sinton G.P. Fluid and solid media for isolation of Brucella abortus. J. Hyg. (Lond). 1975; 74(3):359-67. DOI: 10.1017/ s0022172400046878.

49. Омарова С.М., Ахмедова Э.М., Меджидов Ш.М., Муртузалиева П.М. Питательная среда для выделения бруцелл. Патент РФ № 2266956, опубл. 27.12.2005 г. Бюл. № 36

50. Грубер И.М., Мельникова В.А., Шостак О.А., Черкасова Л.С. Специфическая активность селективной питательной среды для выделения бактерий рода Haemophilus. Эпидемиология и инфекиионные болезни. 2005; 3:15-7.

51. Васильев Д.А., Карпунина Л.В., Щербаков А.А., Назарова Л.С., Швиденко И.Г., Золотухин С.Н. L-формы возбудителей зооантропонозов. Ульяновск: изд-во УГСХА им. П.А. Столыпина; 2013. 118 с.

52. Михайлов Л.М., Маевский М.П., Кузнецов В.И., Калиновский А.И., Татарникова О.Г. Питательная среда для выделения и культивирования L-форм бруцелл. Патент РФ № 2415918, опубл. 10.04.2011 г. Бюл. № 10.

53. Михайлов Л.М., Калиновский А.И., Баранникова Н.Л., Кузнецов В.И., Атлас А.Г., Андреевская Н.М., Михайлова В.А., Татарникова О.Г., Гордиенко Л.Н., Куликова Е.В., Балахонов С.B. Конструирование питательных сред для бруцелл в L-форме. Проблемы особо опасныхх инфекиий. 2012; 3:89-93. DOI: 10.21055/0370-1069-2012-3-89-93.

54. Geresu M.A., Ameni G., Wubete A., Arenas-Gamboa A. 
M., Gezahegne M. K. Isolation and identification of Brucella species from dairy cattle by biochemical tests: The first report from Ethiopia. World Vet. J. 2016; 6(2):80-8. DOI: 10.5455/wvj.20160471.

\section{References}

1. Ponomarenko D.G., Ezhlova E.B., Rusanova D.V., Khachaturova A.A., Pakskina N.D., Berdnikova T.V., Manin E.A. Semenko O.V., Logvinenko O.V., Rakitina E.L., Kostyuchenko M.V., Maletskaya O.V., Kulichenko A.N. Analysis of epizootiologicalepidemiological situation on brucellosis in the Russian Federation in 2018 and forecast for 2019. Problemy Osobo Opasnykh Infektsii [Problems of Particularly Dangerous Infections]. 2019; 2:14-21. DOI: 10.21055/0370-1069-2019-2-14-21.

2. Onishchenko G.G., Kutyrev V.V., editors. [Laboratory Diagnostics of Dangerous Infectious Diseases.Practice Guidelines]. M.: CJSC «Shiko»; 2013. 560 p.

3. Corbel M.J. Food and Agriculture Organization of the United Nations, World Health Organization, World Organization for Animal Health. Brucellosis in humans and animals. Geneva; 2006. 89 p.

4. World Organization for Animal Health. Terrestrial Manual. [Internet]. (Cited 22 Aug 2019). Available from: https://www. oie.int/fileadmin/Home/eng/Health_standards/tahm/3.01.04 BRUCELLOSIS.pdf.

5. Whatmore A.M. Davison N., Cloeckaert A., Al Dahouk S. Zygmunt M.S., Brew S.D., Perrett L.L., Koylass M.S., Vergnaud G., Quance C., Scholz H.C., Dick E.J. Jr., Hubbard G., SchlabritzLoutsevitch N.E. Brucella papionis sp. nov., isolated from baboons (Papio spp.). Int. J. Syst. Evol. Microbiol. 2014; 64(Pt 12):4120-8.

DOI: $10.1099 /$ ijs.0.065482-0.

6. Scholz H.C., Revilla-Fernández S., Al Dahouk S., Hammerl J.A., Zygmunt M.S., Cloeckaert A., Koylass M.S., Whatmore A.M., Blom J., Vergnaud G., Witte A., Aistleitner K., Hofer E. Brucella vulpis sp. nov., isolated from mandibular lymph nodes of red foxes (Vulpes vulpes). Int. J. Syst. Evol. Microbiol. 2016; 66(5):2090-8. DOI: $10.1099 /$ ijsem.0.000998

7. Kazanev A.P., Bulan'kov Yu.I. [Brucellosis]. In: [Guidelines on Infectious Diseases] Lobzin Yu.V., Zhdanov K.V., editors. St. Petersburg: LLC Publishing House "Foliant"; 2011. P. 389-400.

8. Ministry of Health of the Russian Federation. [Brucellosis in Adults. Clinical Guidelines]. 2014.71 p.

9. Taran I.F., Lyamkin G.I. [Brucellosis (microbiology, immunology, epidemiology, prophylaxis)]. Stavropol. 1996. 172 p.

10. Joint FAO/WHO expert committee on brucellosis. World Health Organ. Tech. Rep. Ser. 1986; 740:1-132. PMID: 3097967.

11. The OXOID MANUAL. 9th Edition. 2006. 624 p.

12. [Diagnostics of Particularly Dangerous Infections (PDI) HiMedia Laboratories Pvt. Limited (India). [Electronic source]. Available from: http://www.himedialabs.ru/ooi/ (Cited: August 22, 2019).

13. Sobolev V.V., Mel'nik N.V. Sklyarov O.D., Troynin A.S., Zenov N.I., Klimanov A.I., Shumilov K.V., Litenkova I.Yu., Rakhmanin P.P., Kryukov S.V., Trenev V.N., Solov'ev B.V., Balashov V.G. [Method for the production of brucellous antigen from the strain Brucella abortus 19 for obtaining universal brucellous antigen for agglutination test, complement fixation test, and prolonged complement fixation test, brucellous antigen for rose bengal test (RBT) and brucellous antigen for ring test with milk, method for the production of brucellous diagnostic serum and diagnostic panels]. RF Patent No2361610, published on July 20, 200, Bulletin No 20

14. Pyatkova N.V., Susloparov A.A., Fedotov A.K., Yudnikov V.A., Polishchuk V.I., Okhapkina V.Yu., Darmov I.V. [Method for the production of biomass from brucellous vaccine strains via submerged cultivation using liquid nutrient medium of minimized composition]. RF Patent No 2687373, published on May 13, 2019, Bulletin No 14

15. Kabakhova P.M., Khairov S.G., Yusupov O.Yu., Yanikova E.A. Comparative study of different nutrient media for commercial cultivation of Brucella abortus 19. Veterinarnaya Meditsina [Veterinary Medicine]. 2014; 2:6-8.

16. Devrishov D.A., Shvedov V.V., Shvedov D.V., Bedoeva Z.M. Comparative assessment of growth properties of production brucella cultures on different nutrient media. Veterinarnaya Meditsina [Veterinary Medicine]. 2014; 1:19-34.

17. Kovtun Yu. S., Kurilova A.A., Katunina L.S., Vasilenko E.I. Comparative evaluation of protein hydrolysates in the process of constructing based on them nutrient medium for brucella cultivating. Problemy Osobo Opasnykh Infektsii [Problems of Particularly Dangerous Infections]. 2016; 4:93-97. DOI: 10.21055/0370-10692016-4-93-97.

18. Mamleeva N.K., Torbina M.P., Belozerova G.A. Nutrient medium for diagnostics of brucellosis. Certificate of Authorship of the USSR No 1806186, published on March 30, 1993 Bulletin No12.

19. Zaitseva A.I. Assessment of efficacy of therapeutic brucellous vaccine produced on the medium with yeast autolysate. Zhurnal Mikrobiologii, Epidemiologii i Immunobiologii [Journal of Microbiology, Epidemiology and Immunobiology]. 1961; 1:107-110.
20. Ivanov M.M., Mikhailov N.A. Nutrient medium for cultivation of microorganisms. Certificate of authorship of the USSR No 382682, published on May 23, 1973 Bulletin No. 23.

21. Golovneva S.I., Lyamkin G.I., Katunina L.S., Lyapustina L.V., Startseva O.L., Maletskaya O.V., Efremenko V.I. Nutrient medium for brucella cultivation. RF Patent No 2299238, published on May 20, 2007 Bulletin No 14.

22. Tripathi K.K., Bhatnagar L., Seiffge D., Jankowski R.P., Aikins H.E., Gupta K.G. On the growth of Brucella species in presence of erythritol in defined and undefined media and amniotic fluid of human, cow and sheep. Zentralbl. Bakteriol. Orig. A. 1977; 237(2-3):324-9.

23. Karagül M.S. Evaluation of adding erythritol to Farrell medium for primary isolation of the Brucella melitensis strains. Kocatepe Vet. J. 2019; 12(1):75-81. DOI: 10.30607/kvj.494891.

24. Miranda K.L., Dorneles E.M.S., Poester F.P., Martins Filho P.S., Pauletti R.B., Lage A.P. Different resistance patterns of reference and field strains of Brucella abortus. Braz. J. Microbiol. 2015; 46(1):265-9. DOI: 10.1590/S1517-838246120130625.

25. Devrishov D.A. Kabardiev S.Sh. Yusupov O.Yu. Method for the production of vaccine against brucellosis of small ruminants. RF Patent No 2642316, published on January 24, 2018.

26. Review of the main components of nutrient media. Обзор [Internet]. (Cited 22 Aug 2019). Available from: http://www. dia-m.ru/upload/iblock/34b/Справочник\%20по\%20микробиологии $\% 20 \mathrm{Merck} \% 20$-\%20питательные \%20среды, \%20добавки, \%20экспресс-тесты, \%20пробоотборники \%20воздуха,\%20 русск., $\% 20679 \% 20$ стр..pdf.

27. Gerhardt P., Wilson J.B. The nutrition of brucellae: growth in simple chemically defined media. J. Bacteriol. 1948; 56(1):17-24. PMID: 16561542. PMCID: PMC518538.

28. Rode L.J., Oglesby G., Schuhardt V.T. The cultivation of brucellae on chemically defined media. J. Bacteriol. 1950; 60(5):661-8.

29. Tsygankova R.E., Maisky V.G., Lyapustina L.V., Lyamkin G.I. Synthetic nutrient medium for brucella cultivation. RF Patent No 2148638, published on May 10, 2000

30. Pérez-Etayo L., de Miguel M.J., Conde-Álvarez R., Muñoz P.M., Khames M., Iriarte M., Moriyón I., Zúñiga-Ripa A. The $\mathrm{CO}_{2}$ dependence of Brucella ovis and Brucella abortus biovars is caused by defective carbonic anhydrases. Vet. Res. 2018, 49(1):85. DOI: 10.1186/s13567-018-0583-1

31. Merinov S.P., Shirokov V.A., Golubinsky E.P., Pinigin A.F., Petukhova O.S. Synthetic nutrient medium for brucella cultivation. Certificate of authorship of USSR No 933702, published on June 07 1982 Bulletin No 21.

32. Donskoy D.N., Pinigin A.F., Golubinsky E.P., Merinov S.P. Minimum synthetic nutrient medium for Brucella. Zhurnal Mikrobiologii, Epidemiologii $i$ Immunobiologii [Journal of Microbiology, Epidemiology]. 1983; 60(11):112.

33. Alimov A.M., Zaineev N.Sh., Salmakov K.M., Khazipov N.Z. Synthetic medium for determining saccharolytic activity of brucella. Certificate of authorship of the USSR No 1210453, published on March 23, 1988 Bulletin No 11.

34. Marín C.M., Alabart J.L., Blasco J.M. Effect of antibiotics contained in two Brucella selective media on growth of Brucella abortus, B. melitensis, and B. ovis. J. Clin. Microbiol. 1996; 34(2):426-8.

35. Hornsby R.L. Selective media for isolation of Brucella abortus strain RB51. 1998. [Internet]. (Cited 22 Aug 2019). Available from: https://lib.dr.iastate.edu/cgi/viewcontent. cgi? article $=18852 \&$ context $=$ rtd.

36. Huddleston I. Forrest, Hasley D.E. Torrey J.P. Further studies on the isolation and cultivation of Bacterium abortus (Bang). J. Infect. Dis. 1927; 40(20):352-68. DOI: 10.1093/infdis/40.2.352.

37. Henry B.S., Traum J., Haring C.M. Methods for the isolation of Brucella abortus. Hilgardia. 1932; 6(12):355-79. DOI: 10.3733/hilg.v06n12p355.

38. Kuzdas C.D., Morse E.V. A selective medium for the isolation of brucellae from contaminated materiales. J. Bacteriol. 1953; 66(4):502-4. PMID: 13096514. PMCID: PMC317420.

39. Jones L.M., Morgan W.J.B. A preliminary report on a selective medium for the culture of Brucella, including fastidious types. Bull. World Health Organ. 1958; 19(1):200-3.

40. The Modification of Technical Annexes of Council Directive 64/432/EEC to take account of Scientific Developments regarding Tuberculosis, Brucellosis and Enzootic Bovine Leucosis. [Internet]. (Cited 22 Aug 2019). Available from: http://ec.europa.eu/ food/sites/food/files/safety/docs/sci-com scah out33 en.pdf.

41. Farell I.D. The development of a new selective medium for the isolation of Brucella abortus from contaminated sources. Res. Vet. Sci. 1974; 16(3):280-6. DOI: 10.1016/S0034-5288(18)33726-3. 42. Stack J.A., Harrison M., Perrett L.L. Evaluation of a selective medium for Brucella isolation using natamycin. J. Appl Microbiol. 2002; 92(4):724-8. DOI: 10.1046/j.1365-2672.2002.01595.x.

43. De Miguel M.J., Marin C.M., Munoz P.M., Dieste L., Grillo M.J., Blasco J.M. Development of a selective culture medium for primary isolation of the main Brucella species. J. Clin. Microbiol. 
2011; 49(4):1458-63. DOI: 10.1128/JCM.02301-10.

44. Marin C.M. Jiménez de Bagüés M.P., Barberán M., Blasco J.M. Comparison of two selective media for the isolation of Brucella melitensis from naturally infected sheep and goats. Vet Rec. 1996; 138(17):409-11. DOI: 10.1136/vr.138.17.409.

45. Vicente A.F., Antunes J.M.A.P., Lara G.H.B., Mioni M.S.R. Allendorf S.D., Peres M.G., Appolinário C.M., Listoni F.J.P., Ribeiro M.G., Megid J. Evaluation of three formulations of culture media for isolation of Brucella spp. regarding their ability to inhibit the growth of contaminating organisms. Biomed. Res. Int. 2014; 2014:702072. DOI: $10.1155 / 2014 / 702072$.

46. World Organization for Animal Health. Manual of diagnostic tests and vaccines for terrestrial animals. 6th ed. OIE; 2008. P. 628 .

47. Karagül M.S., İkiz S. Comparison of the isolation and inhibition abilities of selective media used for Brucella spp. Isolation. Turk. J. Vet. Anim. Sci. 2017; 41:781-6. DOI: 10.3906/vet-1701-50. 48. Brodie J., Sinton G.P. Fluid and solid media for isolation of Brucella abortus. J. Hyg. (Lond). 1975; 74(3):359-67. DOI: 10.1017/ s0022172400046878.

49. Omarova S.M., Akhmedova E.M., Medzhidov Sh.M., Murtuzalieva P.M. Nutrient medium for brucella detection. RF Patent No 2266956, published on December 27, 2005 Bulletin No 36.

50. Gruber I.M., Melnikova V.A., Shostak O.A., Cherkasova L.S. The specific activity of selective culture medium for isolation of bacteria of the genus Haemophilus. Epidemiologiya i Infektsionnye Bolezni [Epidemiology and Infectious Diseases]. 2005; 3:15-17.

51. Vasil'ev D.A., Karpunina L.V., Shcherbakov A.A., Nazarova L.S., Shvidenko I.G., Zolotukhin S.N. L-forms of the agents of anthropozoonoses. Ulyanovsk: Publishing house of P.A. Stolypin Ulyanovsk State Agrarian Academy, 2013. 118 p.
52. Mikhailov L.M., Maevsky M.P., Kuznetsov V.I., Kalinovsky A.I. Tatarnikova O.G. Nutrient medium for isolation and cultivation of brucella L-forms. RF Patent No 2415918, published on April 10, 2011 Bulletin No 10.

53. Mikhailov L.M., Kalinovsky A.I., Barannikova N.L., Kuznetsov V.I., Atlas A.G., Andreevskaya N.M. Mikhailova V.A., Tatarnikova O.G., Gordienko L. N. Kulikova E.V., Balakhonov S.V. Construction of nutrient media for L-form brucella. Problemy Osobo Opasnykh Infektsii [Problems of Particularly Dangerous Infections]. 2012; 3:89-93. DOI: 10.21055/0370-1069-2012-3-89-93.

54. Geresu M.A., Ameni G., Wubete A., Arenas-Gamboa A. M., Gezahegne M. K. Isolation and identification of Brucella species from dairy cattle by biochemical tests: The first report from Ethiopia. World Vet. J. 2016; 6(2):80-8. DOI: 10.5455/wvj.20160471.

Authors:

Kovtun Yu.S., Kurilova A.A., Katunina L.S., Vasilenko E.I. Stavropol Research Anti-Plague Institute. 13-15, Sovetskaya St., Stavropol, 355035, Russian Federation. E-mail: stavnipchi@mail.ru.

\section{Об авторах:}

Ковтун Ю.С., Курилова А.А., Катунина Л.С., Василенко Е.И. Ставропольский научно-исследовательский противочумный институт. Российская Федерация, 355035, Ставрополь, ул. Советская, 13-15. E-mail: stavnipchi@mail.ru.

Поступила 01.10.19.

Отправлена на доработку 31.10.19. Принята к публ. 22.11.19. 